\title{
Long Walk Home
}





\title{
Long Walk Home
}

\author{
REFLECTIONS ON \\ BRUCE SPRINGSTEEN
}

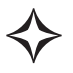

\section{Edited by Jonathan D. Cohen and June Skinner Sawyers}

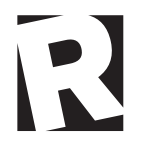

RUTGERS UNIVERSITY PRESS

New Brunswick, Camden, and Newark, New Jersey, and London 
Names: Cohen, Jonathan D., 1990- | Sawyers, June Skinner, 1957-

Title: Long walk home: reflections on Bruce Springsteen / edited by Jonathan D. Cohen and June Skinner Sawyers.

Description: New Brunswick: Rutgers University Press, 2019. | Includes bibliographical references and index.

Identifiers: LCCN 2019002452 | ISBN 9781978805262 (cloth)

Subjects: LCSH: Springsteen, Bruce-Criticism and interpretation.

Classification: LCC ML420.S77 L66 2019 | DDC 782.42166092-dc23

LC record available at https://lccn.loc.gov/2019002452

A British Cataloging-in-Publication record for this book is available from the British Library.

This collection copyright $\odot 2019$ by Rutgers, The State University of New Jersey Individual chapters copyright $\odot 2019$ in the names of their authors

All rights reserved

Natalie Adler's essay "Our Butch Mother, Bruce Springsteen" is based upon the article "My Butch Lesbian Mom, Bruce Springsteen" as first published on Electric Literature (electricliterature.com).

Richard Russo's essay “The Boss in Bulgaria” is excerpted from The Destiny Thief: Essays on Writing, Writers and Life. Copyright $\odot 2018$ by Richard Russo. All rights reserved. No part of this excerpt may be reproduced or reprinted without permission from the publisher.

An earlier version of Wesley Stace's essay "The Magic Circle” was published in Japanese as the preface to Tadd Igarashi's Springsteen Sings America: Long Walk Home to the Land of Hope and Dreams (Ongaku Shuppansha Co., 2009).

"Looking for Elvis," "Like Any Woman Would," “Town Called Heartbreak," "Bad for You," "Rainy Day Man," "Play Around," "Play It As It Lays," and "Black Ladder" by Patti Scialfa. Copyright ( 2007 Rumble Doll Music (ASCAP). Reprinted by permission. International copyright secured. All rights reserved.

"Land of Hope and Dreams" by Bruce Springsteen. Copyright ( 2000 Bruce Springsteen (GMR). Reprinted by permission. International copyright secured. All rights reserved.

"Outlaw Pete," "Working on a Dream," "My Lucky Day," "Queen of the Supermarket," "What Love Can Do," "This Life," "Life Itself," "Kingdom of Days," and "Good Eye" by Bruce Springsteen. Copyright @ 2009 Bruce Springsteen (Global Music Rights). Reprinted by permission. International copyright secured. All rights reserved.

No part of this book may be reproduced or utilized in any form or by any means, electronic or mechanical, or by any information storage and retrieval system, without written permission from the publisher. Please contact Rutgers University Press, 106 Somerset Street, New Brunswick, NJ 08901. The only exception to this prohibition is "fair use" as defined by U.S. copyright law.

@ The paper used in this publication meets the requirements of the American National Standard for Information Sciences-Permanence of Paper for Printed Library Materials, ANSI Z39.48-1992.

www.rutgersuniversitypress.org 